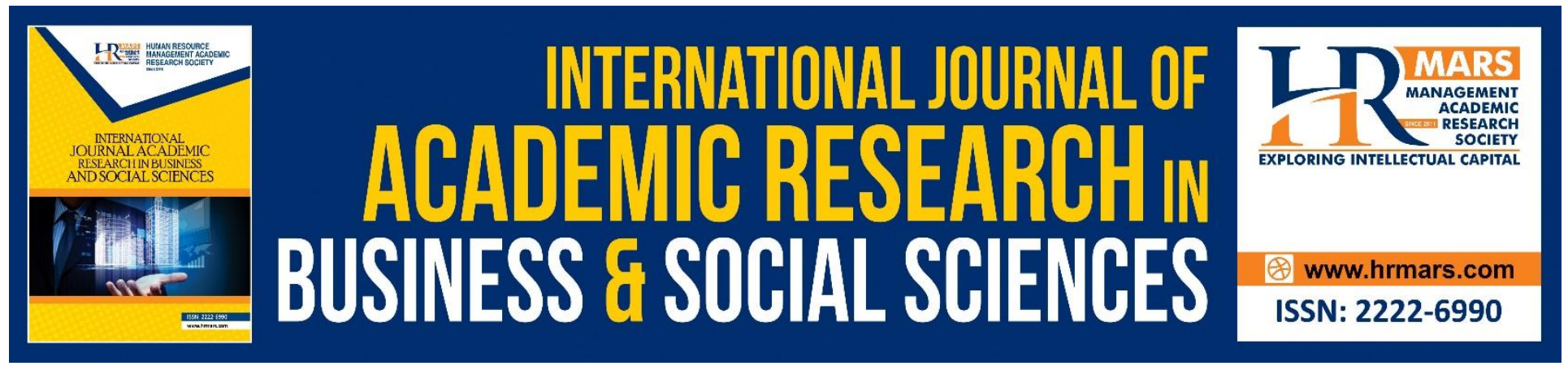

\title{
Mobile Service Delivery Mechanism in Smart Education: Conceptual Framework
}

Roslinda Murad, Supyan Hussin, Md Hanafizah Yaacob, Aslimariah Ahmad

To Link this Article: http://dx.doi.org/10.6007/IJARBSS/v9-i2/5948

DOI: $10.6007 /$ IJARBSS/v9-i2/5948

Received: 22 Dec 2019, Revised: 14 Jan 2019, Accepted: 01 Feb 2019

Published Online: 27 Feb 2019

In-Text Citation: (Murad, Hussin, Yaacob, \& Ahmad, 2019)

To Cite this Article: Murad, R., Hussin, S., Yaacob, M. H., \& Ahmad, A. (2019). Mobile Service Delivery Mechanism in Smart Education: Conceptual Framework. International Journal of Academic Research in Business and Social Sciences, 9(2), 1242-1253.

\section{Copyright: (C) 2019 The Author(s)}

Published by Human Resource Management Academic Research Society (www.hrmars.com)

This article is published under the Creative Commons Attribution (CC BY 4.0) license. Anyone may reproduce, distribute, translate and create derivative works of this article (for both commercial and non-commercial purposes), subject to full attribution to the original publication and authors. The full terms of this license may be seen

at: http://creativecommons.org/licences/by/4.0/legalcode

Vol. 9, No. 2, 2019, Pg. 1242 - 1253

http://hrmars.com/index.php/pages/detail/IJARBSS

JOURNAL HOMEPAGE

Full Terms \& Conditions of access and use can be found at http://hrmars.com/index.php/pages/detail/publication-ethics 


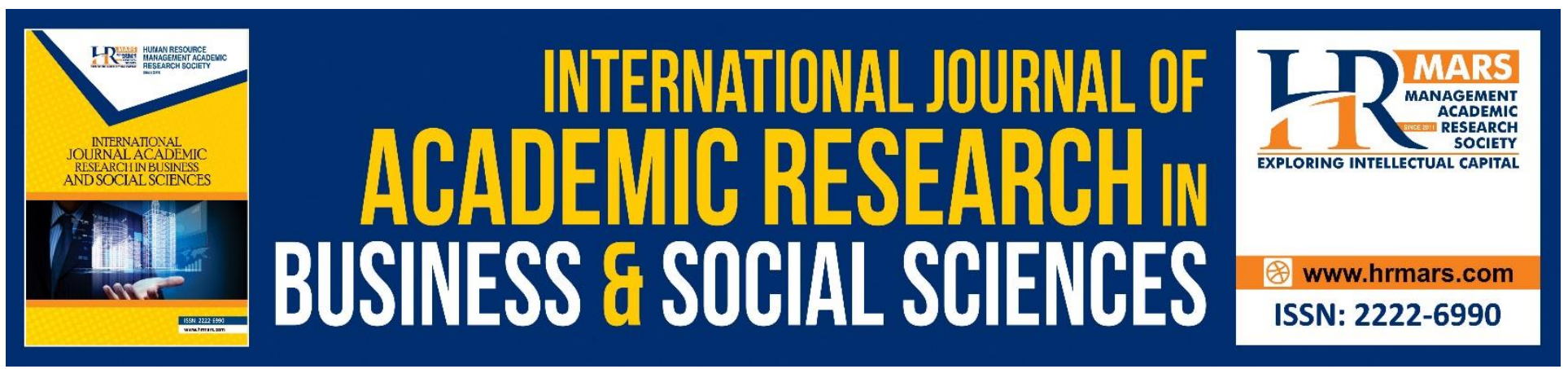

\title{
Mobile Service Delivery Mechanism in Smart Education: Conceptual Framework
}

\author{
Roslinda Murad', Supyan Hussin², Md Hanafizah Yaacob³, \\ Aslimariah Ahmad ${ }^{4}$ \\ 1, 3, 4 Kolej Universiti Poly-Tech MARA, ${ }^{2}$ Universiti Kebangsaan Malaysia, Malaysia
}

\begin{abstract}
Higher education institutions around the world have invested heavily in ICT development to enhance teaching and learning processes and also to meet the needs of students in improving knowledge. As mobile learning has been successful and wider use in developed countries such as Finland, Korea, Japan and so on, so many of higher education institutions in developing countries such as Malaysia have embarked on several mobile learning initiatives to support their traditional learning mods. The objective of this paper is to build a conceptual framework of m-learning involving the integration of current practices, benefits and challenges to know their effectiveness in ensuring the quality of teaching and learning. In addition, the proposed framework focuses on case studies for the service delivery mechanism in smart education at four of the nine branches of Kolej Universiti Poly-Tech MARA (KUPTM) / Kolej Poly-Tech MARA (KPTM) in the context of private higher education institutions in Malaysia. This framework will help students, lecturers and administrators in higher education to tailor educational resources from their mobile devices that can be used anytime and anywhere.
\end{abstract}

Keywords: M-Learning, Mobile Learning, Service Delivery Mechanism, Smart Education, Conceptual Framework.

\section{Introduction}

Along with the evolving and evolution of information technology in today's digital world, the number of users using mobile devices such as smartphones, computer tablets, and personal digital assistants (PDAs) is on the rise. Ye Conghuan (2011) previously identified that managing and supplying educational resources to consumer applications was one of the key challenges for the higher education community. Traditional mode of education, where the transfer of knowledge is achieved through lectures, has some disadvantages, especially since students are not motivated enough to acquire knowledge actively and interactively. Hamdan et al., (2013) also agrees and considers that the lecture room concept should be translated into a new environment as the field of education has changed in tandem with the current technological change. Suhazimah (2016) said that towards a developed nation with the people, the MAMPU is a key player in implementing initiatives to enhance service delivery by prioritizing the public to transform the public service delivery system towards the 
Digital Government. People, Government Agencies, Statutory Bodies and NGOs are the holders of this service delivery system.

Ismail et al., (2017) identifying teaching and learning resources is one of several important factors to consider for effective learning. Therefore, (Ramírez-Donoso et al. (2017) stated that although the e-learning system has a strong platform and supports and stores high data capacity but is limited in the development of certain class activities only. In particular, existing platforms lack equipment to facilitate group work. According to (Lamsah \& Chear, (2017), education today is global and is often linked to the achievement of learning outcomes and marketability of graduates. The advancement of communication and information technology (ICT) has made the world community and an organization more connected with each other in a borderless world community. However, the mechanism of service delivery for the education sector is still low compared to the transportation, fisheries, agriculture, and safety or smart city Z.Ibrahim (n.d.).

\section{Literature Review}

Several domestic and foreign studies have been cited to share discovery of service provision and education, smart learning systems, e-learning and m-learning, mobile applications that can be used as reference material to enhance this research.

Referring to the Communications and Media Resources 2015, the Malaysian Communications and Multimedia Commission showed a high mobile penetration rate of $143.8 \%$, while Internet penetration reached $77 \%$ from 30.68 million Malaysians and 30.8 million broadband subscribers. Most Malaysians also spend more than 6.5 hours a day browsing the internet compared to 78 minutes a day to watch television, 36 minutes a day to listen to radio and 20 minutes a day to read newspapers / magazines. On average, $64 \%$ access the internet via mobile devices compared to desktop computers by $36 \%$. This shows Malaysians are now more comfortable using mobile devices to access information that can be obtained at the fingertips. 
INTERNATIONAL JOURNAL OF ACADEMIC RESEARCH IN BUSINESS AND SOCIAL SCIENCES Vol. 9, No. 2, Feb, 2019, E-ISSN: 2222-6990 @ 2019 HRMARS

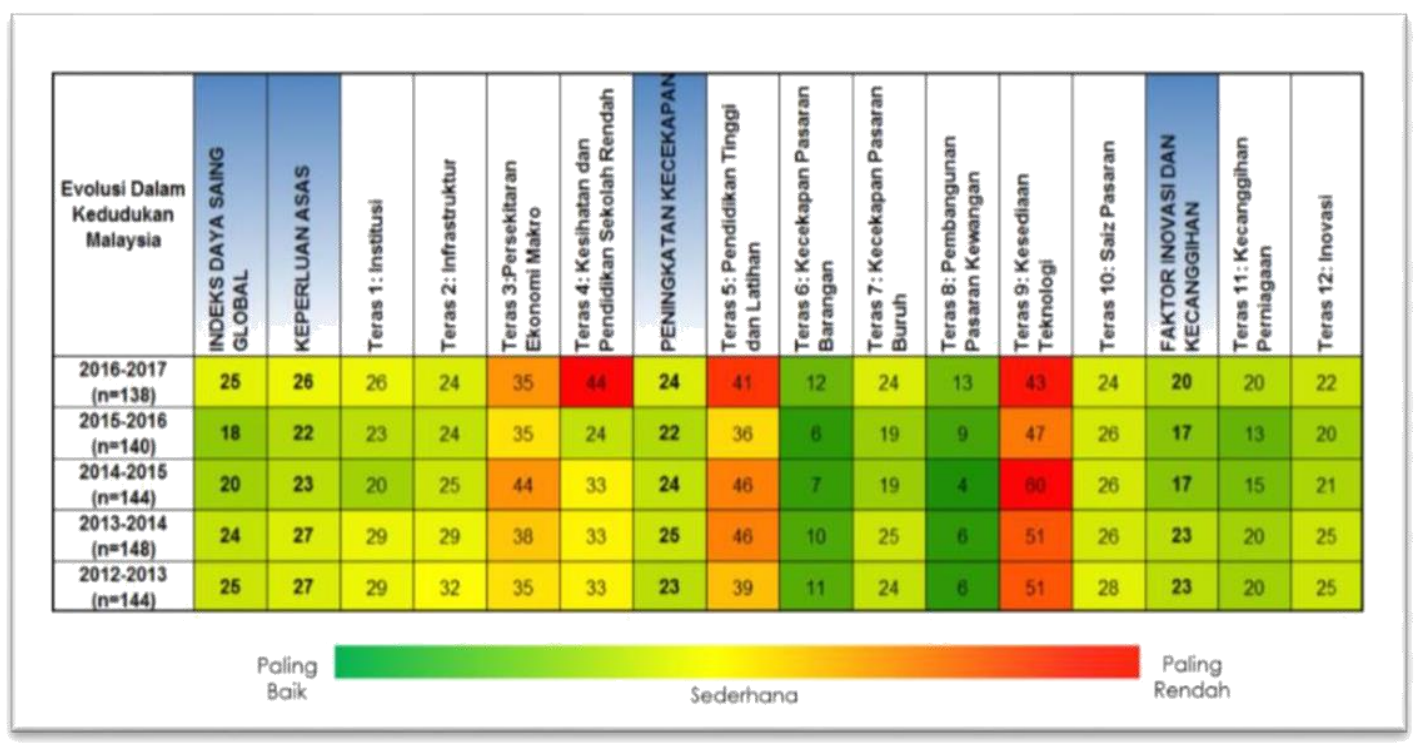

Figure 1. Evolution of Malaysia's Competitiveness Performance

Figure 1 shows the evolution of Malaysia's competitiveness performance, a source from Malaysia in the Global Competitiveness Report 2016-2017, which comprises 12 thrusts from the Good Practice (GCR) 2012-2013 to the GCR 2016-2017. To enhance the country's competitiveness and enhance Malaysia's innovation development stages, more emphasis is required for Technology Readiness (core 9), Higher Education and Training (core 5), Primary School Health and Education (core 4) and Macroeconomic Environment (core 3). Among the indicators showing the fall of the ranking are Higher Education and the 41st Training (GCR 2015-2016: 36) and 44th Health and Primary Education (GCR 2015-2016: 24). This shows that although Malaysia ranked 25th out of 138 countries, leading the region in East Asia and Asia Pacific among new emerging countries but still lagging behind for education and technological readiness. 
INTERNATIONAL JOURNAL OF ACADEMIC RESEARCH IN BUSINESS AND SOCIAL SCIENCES Vol. 9, No. 2, Feb, 2019, E-ISSN: 2222-6990 ㄷ 2019 HRMARS

Table 1. Previous Study by Theme and Year

\begin{tabular}{|c|c|c|c|c|c|}
\hline No & Researcher & $\begin{array}{c}\mathrm{M}- \\
\text { learning }\end{array}$ & $\begin{array}{l}\text { Current } \\
\text { Practice }\end{array}$ & $\begin{array}{l}\text { Benefit } \\
\mathrm{s}\end{array}$ & $\begin{array}{l}\text { Challeng } \\
\text { es }\end{array}$ \\
\hline 1 & $\begin{array}{l}\text { (Flavius \& Ferdi 2011) } \\
\text { (Osman et al. 2014) } \\
\text { (Nascimento 2017) }\end{array}$ & & & & \\
\hline 2 & (Yavari 2016) & & & & \\
\hline 3 & $\begin{array}{l}\text { (Rahman 2016) } \\
\text { (Bhamare et al. 2017) }\end{array}$ & & & & \\
\hline 4 & $\begin{array}{l}\text { (Ye Conghuan 2011a) } \\
\text { (Krish et al. 2012) } \\
\text { (Badusah \& Amin 2013) } \\
\text { (J. A. Lee et al. 2013) } \\
\text { (M. Lee \& Son 2013) } \\
\text { (Salah et al. 2014) } \\
\text { (Sung et al. 2016) } \\
\text { (Kiat et al. 2016) } \\
\text { (Giuliani et al. 2016) } \\
\text { (Syazwani Ismail et al. n.d.) } \\
\text { (Ramírez-Donoso et al. n.d.) } \\
\text { (Jiugen et al. n.d.) } \\
\text { (Zanaton 2017) } \\
\text { (Lamsah \& Chear 2017) } \\
\text { (Noriyani 2017) } \\
\text { (Shen et al. 2017) }\end{array}$ & & & & \\
\hline 5 & $\begin{array}{l}\text { Norliza (2013) } \\
\text { (Analisa Hamdan et al. 2013) } \\
\text { (Khalid \& Yusoff 2016) } \\
\text { (Cheng et al. 2016) } \\
\text { (Fuad \& Deb n.d.) } \\
\text { (Mohd Zainudin n.d.) } \\
\text { (Normah Husin, Nor Azhan Norul 'Azmi } \\
\text { 2017) }\end{array}$ & & & & \\
\hline 6 & (Al-Hunaiyyan et al. 2016) & & & & \\
\hline 7 & $\begin{array}{l}\text { (Asabere 2013) } \\
\text { (Mehdipour \& Zerehkafi 2013) }\end{array}$ & & & & \\
\hline 8 & $\begin{array}{l}\text { (Pholotho \& Mtsweni 2016) } \\
\text { (Zbick n.d.) } \\
\text { (Elaish et al. 2017) }\end{array}$ & & & & \\
\hline \multicolumn{6}{|c|}{ Research } \\
\hline & $\begin{array}{l}\text { Mobile Service Delivery Mechanism in } \\
\text { Smart Education }\end{array}$ & & & & \\
\hline
\end{tabular}


Table 1 shows the previous study with four main themes namely m-learning, current practice, benefits and challenges. According to (Ye Conghuan, 2011b) Managing and supplying educational resources to consumer applications is a major challenge. Meanwhile Analisa Hamdan et al. (2013) identified the concept of the lecture room should be translated into a new environment. Therefore Suhazimah (2016)stated that the MAMPU is implementing initiatives to enhance service delivery by prioritizing the civilians. MAMPU also try transform of the public service delivery system towards the Digital Government. Syazwani Ismail et al. (n.d.) said Teaching and learning resources are an important factor for the effectiveness of active learning. However (Ramírez-Donoso et al., (2017) stated that although the e-learning system has a strong platform and supports and stores high data capacity but is limited in the development of certain class activities only. In particular, existing platforms lack equipment to facilitate group work. In addition (Lamsah \& Chear, (2017) from Universiti Selangor stated education is global and related to the availability of graduates. ICT makes the world borderless and Z.Ibrahim (n.d.) from MAMPU said that Service delivery mechanisms for the education sector are still lower than transport, fishery, agriculture, security or smart city sector.

\section{Issues}

After conducting a past study, several issues have been identified which contribute to the problem of m-learning in Malaysia. According to (Zanaton, 2017), the shortcoming of the traditional learning system that makes students bored is one of the big problems in the classroom.

Meanwhile (Supyan 2016) recognizes that classroom learning giving a lot of impact especially in space usage problems, electrical consumption for printing, high energy consumption and high cost paper usage.

Therefore (Norliza 2013) identified the weaknesses of E-Learning governance and the use of the latest teaching aids as well as lack of e-learning usage guidelines is one of the problems facing education.

However Radzi (2017) states that through a case study in Malaysia, OUM is a pioneering university that conducts large-scale m-Learning in 2004 and was attended by USM in 2010. OUM has been using SMS to deliver notices, reminders and motivational messages to his students. Apart from OUM and USM, it is not well known about any other projects or studies involving other institutions of higher learning that implement such $\mathrm{m}$-Learning scales.

\section{Problem}

There are some problem identified from the previous study which is Service delivery mechanisms for the education sector are still low and lag behind compared to other sectors. (RMK11 2016-2020).

In addition, Malaysia is still lagging and going down to the lowest for education and technological readiness. (Malaysia Competitiveness Evolution 2016/2017)

\section{Proposed Conceptual Framework}

Through the issues and problems of this study, then the conceptual framework proposal has been designed to help solve it 


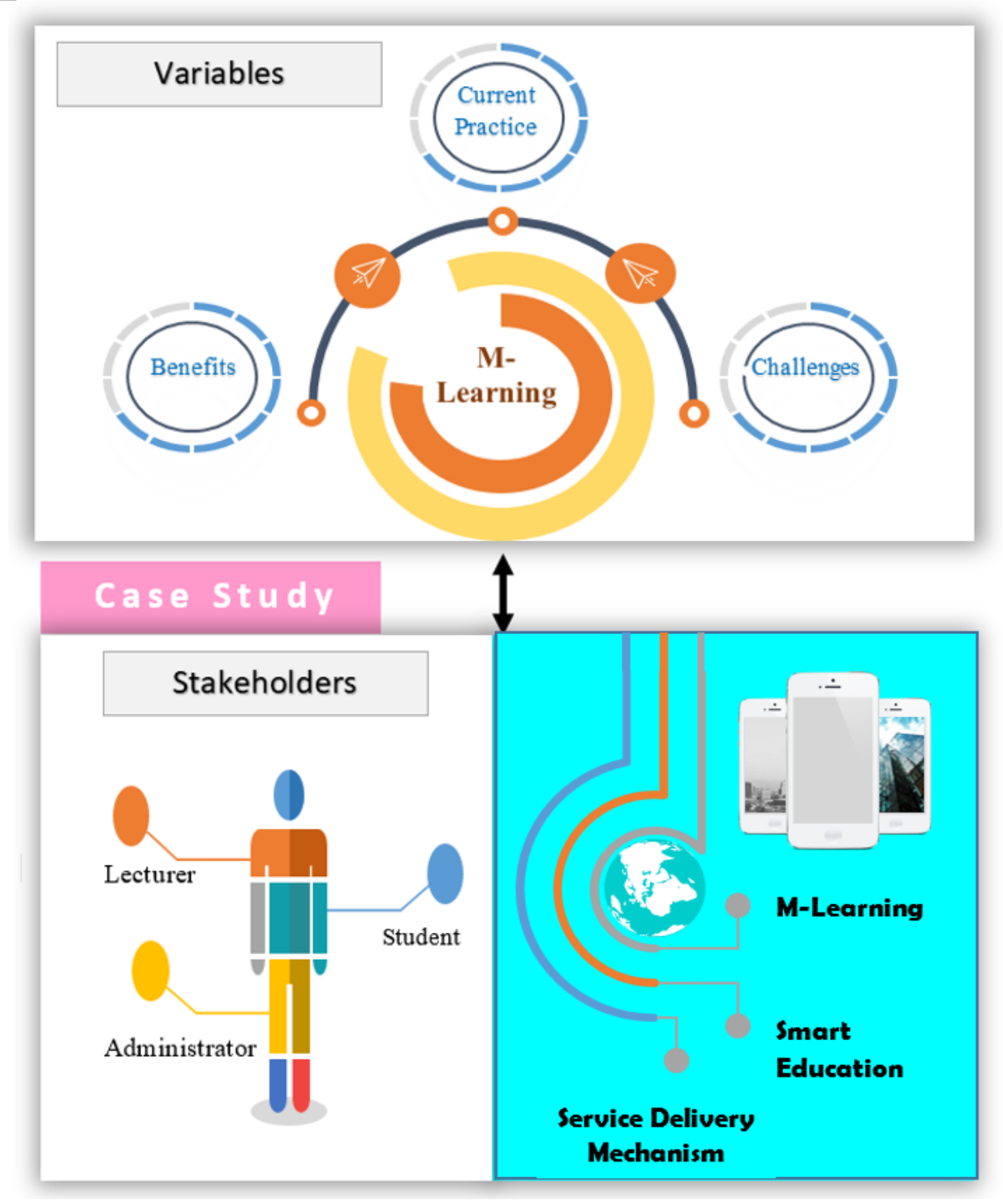

Figure 2. Conceptual Framework

Figure 2 shows the conceptual framework for this study which consists of variables and case study.

\section{Conceptual Framework Elements}

There are some key elements in the study such as current practices, benefits and challenges as indirect variables while direct variables are m-Learning. Current practice variables are mediators between benefit variables and challenges. A case study will be conducted at the Kolej Universiti PolyTech MARA (KUPTM) and Kolej Poly-Tech MARA (KPTM) which involves lecturers, students and administrators as stakeholders who relate to each other in the context of service delivery mechanisms, smart education and m-Learning. 


\section{- Current Practices}

To examine current practices on acceptance of $\mathrm{m}$-Learning based on mobile apps and conduct self-study.

- Benefits

To explore the benefits of m-learning to improve the learning process in a smart education.

- Challenges

Reviewing challenges that affect users when implementing m-Learning.

- M-Learning

Mobile learning is a form of distance education that "learns through various contexts through social interaction and its content using personal electronic devices". As a distance education form, students use mobile learning technology at the right time and everywhere (Mehdipour \& Zerehkafi, 2013).

\section{- Lecturer}

Helps to transform traditional learning into local communities into blended learning that enables lecturers and supervisors to provide effective education, and help them access the mobile teaching world and evaluate their student performance continuously. In addition, lecturers can also disseminate important information to students by using their mobile devices anytime and anywhere quickly and easily.

- Student

Encourage students to activate their mobile devices; download mobile apps to support the $\mathrm{m}$-Learning process, and utilize them anytime and anywhere and have wireless networks available (Wi-Fi, 3G, 4G). In addition, it can help students to get the information they need especially in learning as in developed countries.

- Administrator

Spell the name of the institution by helping, managing and implementing $\mathrm{m}$-Learning.

- Service Delivery System

The service delivery system is a set of principles, standards, policies and constraints that will be used to guide the design, development, use, operation and retirement of services provided by the service provider in order to offer a consistent service of a particular user community within the context of a particular business. The mechanism of delivery mechanisms is the context in which the capabilities of service providers are organized into service (W.M. Zawawi, 2015). 


\section{- Smart Education}

The next generation of learning concepts, smart learning environment, and smart classroom concepts appear. Learning space is a new field of research aimed at promoting free, flexible learning and dealing with providing learning skills and appropriate learning methods (Zhuang et al., 2017).

\section{Conclusion}

M-learning is an alternative education of various educational patterns in the Malaysia. The suitability is significant for students at higher education level particularly for courses requiring a lot of campus studies. For those with disabilities or those who unable to attend school, this approach is very useful. Mobile Learning is a more engaging and effective learning pattern for teens who love challenges in life, and those who want to learn while working as vocational and technical course participants. Mobile learning if implemented will help people from all levels improve the quality of life in the era of modern technology.

\section{Future Work}

This framework is also proposed to be tested in higher education institutions in developed and developing countries. By using this framework at the same higher educational institution, we can measure the increase in the learning process in higher education. Furthermore, many studies have to be conducted to determine the challenges faced and the use of m-learning in higher education. In addition, the proposed m-learning framework for higher education institutions can be expanded to support and adapt to new mobility tools and technologies.

\section{Acknowledgement}

The author would like to thank Prof. Dr. Supyan Hussin (Supervisor) ATMA, Universiti Kebangsaan Malaysia and management of Kolej University Poly-Tech MARA (KUPTM) that have helped in conducting this study.

\section{Corresponding Author}

Roslinda binti Murad - Kolej Universiti Poly-Tech MARA Kuala Lumpur, Malaysia, Email: roslinda@kuptm.edu.my

\section{References}

Al-Hunaiyyan, A., Alhajri, R. A. \& Al-Sharhan, S. 2016. Perceptions and challenges of mobile learning in Kuwait. Journal of King Saud University - Computer and Information Sciences. doi:10.1016/j.jksuci.2016.12.001

Hamdan, A., Din, R., \& Manaf, S. Z. A. (2013). Penerimaan m-Pembelajaran dalam Sintem Pendidikan di Malaysia melalui The Unified Theory of Acceptance and Use of Technology (UTAUT): Satu Analisis Literatur. 1st International Conference on Mobil Learning, Applications, and Services (mobilcase2012) 1(2): 93-97.

Asabere, N. Y. (2013). Benefits and Challenges of Mobile Learning Implementation: Story of Developing Nations 73(1): 23-27. 
INTERNATIONAL JOURNAL OF ACADEMIC RESEARCH IN BUSINESS AND SOCIAL SCIENCES

Vol. 9, No. 2, Feb, 2019, E-ISSN: 2222-6990 @ 2019 HRMARS

Badusah, J. \& Amin, M. (2013). PENGGUNAAN M - PEMBELAJARAN : SATU INOVASI DALAM PEMBELAJARAN BAHASA MELAYU (2010): 719-726.

Bhamare, D., Erbad, A., Jain, R., \& Samaka, M. (2017). Automated service delivery platform for CRANs. 2017 2nd International Conference on Fog and Mobile Edge Computing, FMEC $2017219-$ 224. doi:10.1109/FMEC.2017.7946434

Cheng, H., Kung, T., Li, C.. \& Sun, Y. (2016). The Current State of Mobile Apps Development of Higher Education in Taiwan. ICACT Transactions on Advanced Communications Technology (TACT) 5(2): 780-786.

Elaish, M. M., Shuib, L., Ghani, N. A., Yadegaridehkordi, E. \& Alaa, M. (2017). Mobile learning for English Language Acquisition: Taxonomy, Challenges, and Recommendations. IEEE Access. doi:10.1109/ACCESS.2017.2749541

Flavius, P. \& Ferdi, P. (2011). Internet Service Delivery Models: Evolution and Current Issues. CyberEnabled Distributed Computing and Knowledge Discovery (CyberC), 2011 International Conference on 146-153. doi:10.1109/CyberC.2011.33

Fuad, M. M. \& Deb, D. (n.d.). Cloud-Enabled Hybrid Architecture For In-Class Interactive Learning Using Mobile Device. doi:10.1109/MobileCloud.2017.15

Giuliani, F., Ottavi, M., Cardarilli, G. C., Re, M., Di Nunzio, L., Fazzolari, R., Bruno, A., et al. (2016). Design and characterization of a high-safety hardware/software module for the acquisition of Eurobalise telegrams. 2016 IEEE International Symposium on Defect and Fault Tolerance in VLSI and Nanotechnology Systems, DFT 2016. doi:10.1109/DFT.2016.7684080

Ibrahim, Z. (n.d.). Malaysian Experience of the Framework of Sharing: Malaysia Public Service Delivery 1-31.

Jiugen, Y., Rongrong, K. \& Ruonan, X. (n.d.). Design and Development of SCORM-based Mobile Learning System. doi:10.1109/ITME.2016.121

Khalid, F. \& Yusoff, N. 2016. TAHAP KESEDIAAN PELAJAR PRASISWAZAH UKM DALAM PENGGUNAAN M-PEMBELAJARAN 2016(November).

Kiat, L. B., Ali, M. B., Halim, N. D. A. \& Ibrahim, H. B. (2016). Augmented Reality, Virtual Learning Environment and Mobile Learning in education: A comparison. 2016 IEEE Conference on eLearning, e-Management and e-Services (IC3e). doi:10.1109/IC3e.2016.8009034

Krish, P., Hussin, S., Manap, M. R. \& Amir, Z. (2012). Mobile learning readiness among Malaysian students at higher learning institutes. Asian Social Science 8(12): 276-283. doi:10.5539/ass.v8n12p276

Lamsah, S. \& Chear, S. (2017). Pengajaran dan Pembelajaran Melalui Aplikasi Whatsapp dan Telegram di Universiti Swasta 42(2).

Lee, J. A., Kim, T. H. \& Chung, J. H. (2013). Study on communication of characteristics smart learning from UX perspective. International Journal of Smart Home 7(6): 59-72.

doi:10.14257/ijsh.2013.7.6.06

Lee, M. \& Son, Y. (2013) A study of learning system for Smart Learning using BYOD. SERSC: Science \& Engineering Research Support soCiety 19: 106-111.

Mehdipour, Y. \& Zerehkafi, H. (2013). Mobile Learning for Education: Benefits and Challenges. International Journal of Computational ... 3(6): 93-101 (251-259).

doi:10.1080/87567555.2011.604802 
INTERNATIONAL JOURNAL OF ACADEMIC RESEARCH IN BUSINESS AND SOCIAL SCIENCES

Vol. 9, No. 2, Feb, 2019, E-ISSN: 2222-6990 @ 2019 HRMARS

Mohd Zainudin, J. (n.d.). National Innovation and Invention Competitio $\mathrm{n}$ Through Exhibition (iCompEx' 17).

Nascimento, D. M. (2017). Information flows in e-participation applications: Implications in government service-delivery in Brazil. International Conference on Information Society, i-Society 2016 (2): 51-52. doi:10.1109/i-Society.2016.7854172

Noriyani, D. (2017). IMPLIKASI GOOGLE APPS DALAM PENGAJARAN DAN PEMBELAJARAN PELAJAR PESISIR UTHM (July).

Norliza, R. (2013). PENGGUNAAN MOBILE LEARNING (M-LEARNING) UNTUK TUJUAN PEMBELAJARAN DALAM KALANGAN PELAJAR KEJURUTERAAN UTHM. Thesis (Jun): 1-75. Retrieved from http://plato.stanford.edu/archives/win2013/entries/phenomenology/

Normah Husin, Nor Azhan Norul 'Azmi, \& M. M. D. (2017). Pembelajaran Kolaboratif Melalui Aplikasi Telefon Pintar Dalam Pembelajaran Nahu. e-JURNAL PENYELIDIKAN DAN INOVASI 4(1): 43-63.

Osman, M. M., Bachok, S., Bakri, N. I. M. \& Harun, N. Z. 2014. Government Delivery System: Effectiveness of Local Authorities in Perak, Malaysia. Procedia - Social and Behavioral Sciences 153: 452-462. doi:10.1016/j.sbspro.2014.10.079

Pholotho, T. \& Mtsweni, J. (2016). Barriers to electronic access and delivery of educational information in resource constrained public schools: A case of Greater Tubatse Municipality. 2016 IST-Africa Conference, IST-Africa 2016 1-9. doi:10.1109/ISTAFRICA.2016.7530626

Rahman, I. 2016. New Perspectives on Design and Delivery: the Context of Service Desk. doi:10.1177/0741713604268894

Ramírez-Donoso, L., Rojas-Riethmuller, J. S., Pérez-Sanagustín, M. \& Neyem, A. (n.d.). Enhancing Collaborative Learning in Higher Education Online Courses through a Mobile Game App.

Salah, A., Lela, M. \& Al-zubaidy, S. (2014). Smart Education Environment System 4(4): 21-27.

Shen, Y., Lee, J., Jeong, H., Jeong, J., Lee, E. \& Du, D. H. C. 2017. SAINT+: Self-Adaptive Interactive Navigation Tool+ for Emergency Service Delivery Optimization. IEEE Transactions on Intelligent Transportation Systems 1-16. doi:10.1109/TITS.2017.2710881

Suhazimah, D. (2016). Kerajaan Digital Inklusif Pemacu 7.

Sung, Y. T., Chang, K. E. \& Liu, T. C. (2016). The effects of integrating mobile devices with teaching and learning on students' learning performance: A meta-analysis and research synthesis. Computers and Education 94: 252-275. doi:10.1016/j.compedu.2015.11.008

Supyan, H. 2016. Mobile Learning for the green environment. The 1st International Conference on Green Development (GDIC 2016) (Gdic).

Syazwani Ismail, N., Harun, J., Aman Zahiri Megat Zakaria, M. \& Md Salleh, S. (n.d.). The Effect of Mobile Problem-Based Science Dictionary Application DicScience PBL Towards Students' Mastery of Scientific Terms and Critical Thinking. doi:10.1109/LaTiCE.2017.19

W.M. Zawawi, W. R. (2015). Berprestasi Tinggi. Retrieved from http://slejournal.springeropen.com/articles/10.1186/s40561-017-0044-8

Yavari, A. 2016. Contextualised Service Delivery in the Internet of Things 1-6.

Ye Conghuan. (2011)a. Service delivery using social network analysis in P2P supportive e-learning environment. Computer Science I\& Education (ICCSE) ,6th International Conference (Iccse): 411415. doi:10.1109/ICCSE.2011.6028667

Ye Conghuan. (2011)b. Service delivery using social network analysis in P2P supportive e-learning 
INTERNATIONAL JOURNAL OF ACADEMIC RESEARCH IN BUSINESS AND SOCIAL SCIENCES

Vol. 9, No. 2, Feb, 2019, E-ISSN: 2222-6990 @ 2019 HRMARS

environment. Computer Science I\& Education (ICCSE) ,6th International Conference (Iccse): 411415. doi:10.1109/ICCSE.2011.6028667

Zanaton, H. I. (2017). Mobile learning: innovation in teaching and learning using telegram 1(1): 1926.

Zbick, J. (n.d.). A Web-based Reference Architecture for Mobile Learning: Its Quality Aspects and Evaluation. doi:10.1109/ICSAW.2017.8

Zhuang, R., Fang, H., Zhang, Y., Lu, A. \& Huang, R. (2017). Smart learning environments for a smart city: from the perspective of lifelong and lifewide learning. Smart Learning Environments 4(1): 6. doi:10.1186/s40561-017-0044-8 